allocations of subjects as above indicated, namely, meteorology, geomagnetism, aurora, and aerology. While a large part of the available funds has been set aside for the items already approved, there is still a small balance unappropriated, which must be returned if not expended before 31 December 1950. It is therefore urgent that persons having any reductions or analyses in mind should communicate synopses of the work contemplated and estimates of funds needed to Dr V. Laursen, the executive officer of the central bureau in Copenhagen. The commission also requests anyone who has already published results or who is planning further research based on data obtained during the Second International Polar Year to communicate with the commission as soon as possible.

\title{
NEW REGULATIONS CONCERNING TRAVEL TO AND IN GREENLAND, 1948
}

[From Kundgarelser vedrorende Gronlands Styrelse, 1948, Nr. 5, p. 65-67. This notice replaces the regulations for travel in Greenland published in Kundgorelser vedrorende Gronlands Styrelse, 1939, Nr. 2, p. 22-23, which came into force on 15 May 1939.]

\section{Translation:}

"1. Unless anything to. the contrary has been provided by special treaty between Denmark and a foreign country or by other special arrangement, no travel to or in Greenland can be undertaken without special permission from the Danish Government.

"2. Danish citizens who desire a travel permit must in reasonable time before departure forward an application to Statsministeriet, Gronlands Styrelse [Greenland Administration].

" 3 . Foreigners who desire a travel permit must in reasonable time before departure forward an application to the Danish Government through the Government of their own country.

"4. The application, or a programme for the journey appended to it, must include information about the following points:

"(a) The names of those travelling and their nationality.

" (b) The proposed route, especially if the traveller desires to be conveyed by ships of Grønlands Styrelse, or if he can provide his own transport to and from Greenland as well as for journeys in Greenland.

" $(c)$ The time when he desires to arrive in Greenland and the contemplated duration of his stay there.

"(d) The object of the journey.

"(e) Which places and areas he intends to visit.

" $(f)$ The probable equipment to be taken, including scientific apparatus, travelling equipment and provisions, including spirits. If the traveller desires the equipment to be transported by Grønlands Styrelse ships, weight and volume must be stated.

"5. Prior to departure such security must be found as may be required by Gronlands Styrelse to cover any amount due to them for transport, freight, cash advances and supplies during the stay in Greenland. 
"6. Part 1. All travellers to Greenland must produce on the day prior to departure a medical certificate stating that they are not suffering from any contagious disease which might be dangerous to the Greenland population when in contact with them.

"Part 2. Should the departure be made from a foreign port the certificate should be signed by the Danish Consul or Vice-Consul who must testify that the certificate was issued by an authorised doctor, and in addition an ordinary bill of health must be procured from the local authorities certifying that to their knowledge no epidemic disease of any kind is prevalent in the port of departure.

"7. In Greenland travellers must observe the game protection laws in force at the time, conform with the ordinary regulations in force there, and follow directions given by the authorities.

"8. Any expedition that wishes to give geographical names to localities visited must forward the proposals to the Danish Government, which will make the final decision. Before this decision has been made the proposed names may not be used in publications, or in maps connected with them.

"9. The following special orders concern scientific expeditions:

"Part 1. The travel permit when issued cannot be used for investigations in any other areas than those stated in the permit.

"Part 2. It must not be expected that permission will be given to export archaeological, ethnographical, anthropological, mineralogical or any other scientific collections. However, exceptions may be made for public institutions. Furthermore, it must be expected that permission will only be given on condition that Danish museums have the right to select from a collection anything which may be of importance for supplementing their own collections. All items of this kind must always be forwarded via Copenhagen, where they must be placed at the disposal of the Danish authorities even if the persons concerned are using their own transport.

"Part 3. Two copies of any paper, book or map that is published as a result of investigations in Greenland must be sent to the Danish Government.

"10. In each case a travel permit can be issued subject to any special conditions determined by Grønlands Styrelse.

"11. Part 1. If the provisions of this notice are infringed, a fine will be imposed.

"Part 2. Should infringements recur, or in case of a major infringement, the travelling equipment and collections may be confiscated. Likewise the persons concerned may be expelled from Greenland.

"Part 3. Fines imposed after the date of this notice go to the State Exchequer. Gronlands Styrelse will decide what shall be done with confiscated effects.

"12. 'General regulations for travel to and in Greenland' of 15 May 1939 is hereby cancelled.

"Statsministeriet, Grønlands Styrelse, 20 May 1948." 